\title{
The Value of Pig Manure as a Source of Nutrients for Semi-Intensive Culture of Nile Tilapia in Ponds (A Review)
}

\author{
Christopher L. Brown'1*, Tingbao Yang2, Kevin Fitzsimmons ${ }^{3}$, Remedios B. Bolivar4 \\ ${ }^{1}$ National Oceanic and Atmospheric Administration, Aquaculture and Enhancement Division, The Milford \\ Laboratory, Milford, USA \\ ${ }^{2}$ State Key Laboratory of Biocontrol and Center for Parasitic Organisms, School of Life Sciences, Sun Yat-sen \\ University, Guangzhou, China \\ ${ }^{3}$ Department of Soil, Water and Environmental Science, University of Arizona, Tucson, USA \\ ${ }^{4}$ College of Fisheries, Central Luzon State University, Science City of Muñoz, Nueva Ecija, Philippines \\ Email: ${ }^{*}$ Christopher.L.Brown@noaa.gov
}

Received 21 August 2014; revised 22 September 2014; accepted 22 October 2014

Copyright (C) 2014 by authors and Scientific Research Publishing Inc.

This work is licensed under the Creative Commons Attribution International License (CC BY).

http://creativecommons.org/licenses/by/4.0/

(c) (i) Open Access

\begin{abstract}
Growing global needs for food call for substantial increases in protein production in coming years, and for diligent conservation efforts. Manures from farm animals have been viewed both as a resource and as a waste product, but they are critically important sources of nutrients for organic and integrated farming and for traditional Asian aquaculture. Given constraints on livestock production and capture fisheries, careful development of the aquaculture industry is a necessity. The production volume and market share of tilapia are advancing extremely rapidly, and so too is the proliferation of misinformation and controversy. Culture and feeding practices differ widely, but feeding is usually recognized as the single largest cost to producers. Traditional Asian integrated farming practices involve the use of manures and other farm wastes to promote algae and zooplankton production, serving as a sole or supplemental nutrient source to the food chain that supports tilapia growout. Tilapia also ingest manures. The efficient use of nutrients from manures can have multiple benefits to integrated terrestrial agriculture and aquaculture, as long as product safety and quality are not compromised. With efficient use, handling of manures is simplified, fish production costs are reduced, fish nutrition can be improved, and potentially polluting materials are cycled constructively on integrated farms. Consumer and press reactions to the use of farm manures in food production can be highly polarized. Published responses cover a range of extremes, from enthusiastic endorsement to volatile reactions and outright rejection; in some areas this practice is considered to be more of a "PR (Public Relations) problem" than a health hazard. The perception in online public media that tilapia coming from ponds fertilized with manure are
\end{abstract}

"Corresponding author.

How to cite this paper: Brown, C.L., Yang, T.B., Fitzsimmons, K. and Bolivar, R.B. (2014) The Value of Pig Manure as a Source of Nutrients for Semi-Intensive Culture of Nile Tilapia in Ponds (A Review). Agricultural Sciences, 5, 1182-1193.

http://dx.doi.org/10.4236/as.2014.512128 
heavily contaminated with pathogens has not been supported by evidence. The perspectives of farmers in two major tilapia production areas (China and the Philippines) are included.

\title{
Keywords
}

\author{
Tilapia, Manure, Nutrition, Phytoplankton, Omega-3 Fatty Acids
}

\section{Introduction}

Global concern has been elevated over the increasing need for protein as the human population edges toward a predicted 9.6 billion by 2050 [1]. This concern is amplified because conventional livestock and capture fisheries production appear to be incapable of meeting this demand. Aquaculture is developing steadily in response to current and anticipated needs, with annual growth worldwide at more than 7\% [2]. Supply and demand principles and increasing profitability have driven continuous aquaculture industry growth. Demand on a per capita basis is also increasing; details of the benefits of seafoods to human health continue to be revealed, and draft recommendations by the US Food and Drug Administration for seafood consumption have again been revised upward, to two or three servings per week [3]. Tilapia have been specified as a desirable part of the human diet, especially for pregnant women and growing children [3]. Annual fish consumption globally has increased to 42 pounds per person from 25 pounds in the 1970s, and continues to rise [4]. Seafood-about half of which is now produced by aquaculture - conveys a range of public health benefits, as compared with "western-style" diets that are based on the consumption of factory-farmed livestock and processed foods [5].

The UN Food and Agriculture Organization (FAO) has been promoting Conservation Agriculture, the use of a set of principles designed for sustainable improvements in terrestrial food production [6]. Reduced surface disturbance by tillage, increased mulching of soils, crop rotation [7] and improved utilization of nutrients from manures and food wastes [8] are key components of the Conservation Agriculture approach. Goals of this strategy include improvements in the long-term health and productivity of soils, but these principles have not been linked directly to aquatic food production. The term "Conservation Aquaculture" has been used in a different context, in reference to recently-developed standards for environmentally-sensitive hatchery reform [9]. Integration of agriculture and aquaculture as practiced on small farms that make use of animal manures could fit well with the Conservation Agriculture ideology.

One common view is that the majority of capture fisheries have been pushed to or beyond their capacity. Managed properly they may recover, but it is unlikely that capture fisheries are capable of expanding to meet increasing demand. As concluded in one recent update, "The bottom line is that getting much more food from natural systems may not be possible" [4]. For these reasons, aquaculture is very much on the rise and tilapia culture in particular is increasing at a phenomenal rate (Figure 1). Because Nile tilapia (Oreochromis niloticus) are hardy, omnivorous and fast-growing fish that are tolerant of highly variable culture conditions, they have emerged among the most prominent candidates for mass-culture. Tilapia production shows no sign of slowing or leveling off. The numerous desirable qualities of tilapia as a major human food source include their low trophic level, which is appealing both ecologically and economically. This makes production independently of processed ingredients possible, and the accumulation of hazardous materials preventable.

Pork production continues to increase at a moderate pace and retains the first rank among protein sources for human nutrition, with poultry in the second position [10]. Steady growth in aquaculture production has resulted in the passing of both capture fisheries and beef production [4]. Relatively modest increases in beef, pork, mutton, and poultry production reflect limitations in the availability of suitable infrastructure. Feeds, commitments of space to terrestrial agriculture, processing and distribution facilities, and the generation of manures and other materials impose limitations on the capacity and efficiency of terrestrial meat production. Excessive reliance on antibiotics for disease control is a serious concern in factory farming, as is the efficiency of protein production. The production of cattle requires about $7 \mathrm{~kg}$ of feed to produce $1 \mathrm{~kg}$ of live weight product, pork production requires more than $3 \mathrm{~kg}$ of feed, chicken more than $2 \mathrm{~kg}$ of feed, and tilapia less than 2 [11]. The production of terrestrial meats competes with other land uses, depletes and pollutes water, consumes large amounts of grain, negatively impacts biodiversity, and has an enormous carbon footprint [12]. Groundwater contamination with 


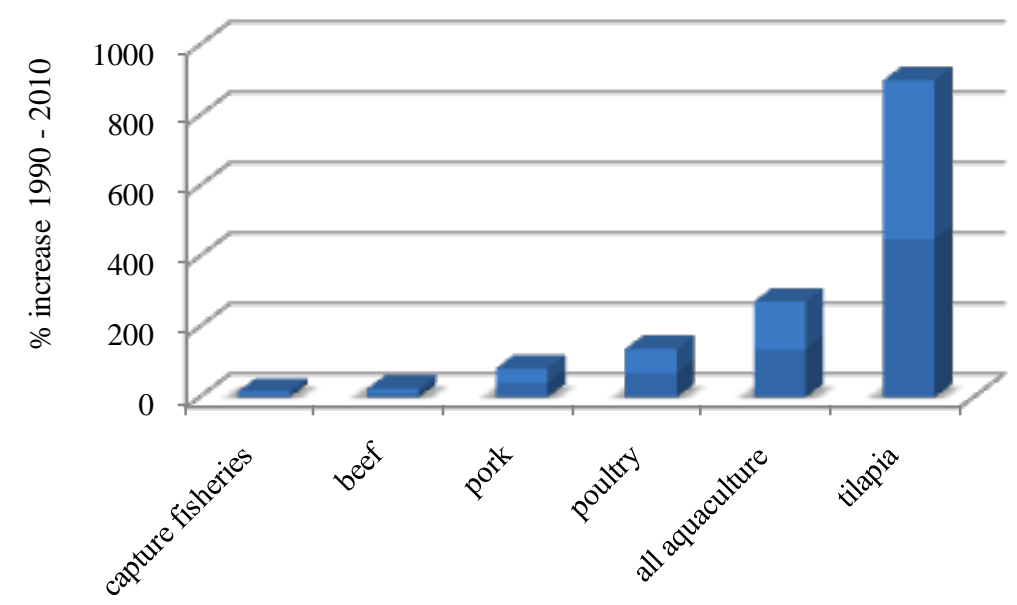

Figure 1. The percentage of increase in production by mass between 1990 and 2010; FAO data from FAOSTAT and FishStat.

fecal coliform bacteria and various other pathogens from untreated manure is a major problem in swine and other livestock producing areas, routinely resulting in threats of human disease outbreaks [13] [14]. Terrestrial livestock farming has been identified by the United Nations Food and Agriculture Organization as a significant contributor to serious environmental problems [15], and far-reaching corrective actions have been recommended. Those recommendations emphasize the need for more constructive handling and use of manures and for more efficient uses of feeds. Approximately 36\% of the grain currently grown on earth is used for livestock feeds; for this reason, improved grain use efficiency gained by continuing the shift to aquaculture could result in desperately needed increases in food production both on land and in the water [11]. It has been forecast that "Because of their substantially better feed conversion ratio than livestock (typically 1.6 to 1.8 for tilapia), aquaculture may play the role poultry played in the past, depressing feed demand for cereals” [16]. Further similarities of tilapia to the poultry industry are discussed below.

Trends favoring tilapia culture have transformed its market acceptability. Tilapia were formerly snubbed in seafood markets as an undesirable "junk fish" alternative, since tilapia were often associated with the contaminated waters they can tolerate. Tilapia feeding on certain types of phytoplankton, especially blue-green algae, can acquire off-flavors [17] [18]. Depuration or purging of harvested tilapia before marketing them eliminates a majority of off-flavors and most contamination with waste-materials [19]. A surge in the availability of fresh and frozen tilapia that are free of off-flavors, and at relatively low prices has occurred, as wild marine fishes have simultaneously become more scarce and expensive. The result is a net growth in the market share for tilapia. The steady and vigorous growth patterns for production and consumption of tilapia resemble earlier patterns of growth in the poultry industry (Figure 2, and see [20]). Increasing availability of high-quality, frozen fillets primarily from China have induced a shift on the global market from wild-caught marine fish to farmed tilapiaproducts, at very affordable prices. Improvements in production methods and steady increases in supply were accompanied by a consistent pattern of falling wholesale prices from 1997 to 2007, but after that prices for frozen tilapia fillets appear to have stabilized, while prices for fresh fillets remain elevated [21] [22]. Tilapias occupy a low trophic level and are therefore not subject to the intensive biomagnification of mercury, pesticides, and other hazardous materials that has plagued wild marine food chains (see [23]), in part because tilapia can be produced with little or no reliance on dietary fishmeal [24]. The consumption of grains, fishmeal, and other ingredients in processed feeds can be reduced or eliminated by the promotion of pond productivity with manures. Tilapias are often singled out as a promising candidate for culture on a mass scale; as stated by Cressey [25], "Oreochromis niloticus, the Nile tilapia.... affectionately dubbed the aquatic chicken for their speedy and efficient growth —are to many a nearly perfect aquaculture species”. The New York Times has referred to tilapia as "the perfect factory fish" [26]. The biological characteristics and culture requirements of tilapia qualify these fishes for a centrally important role in the sustainable feeding of the human population [11] [24].

Advances in poultry science spurred the growth and maturation of the chicken and turkey industries. Improvements in the efficiency of poultry production through selective breeding and nutritional science have dramatically reduced costs and improved yields; modern chickens grown for meat gain weight $300 \%$ faster than 


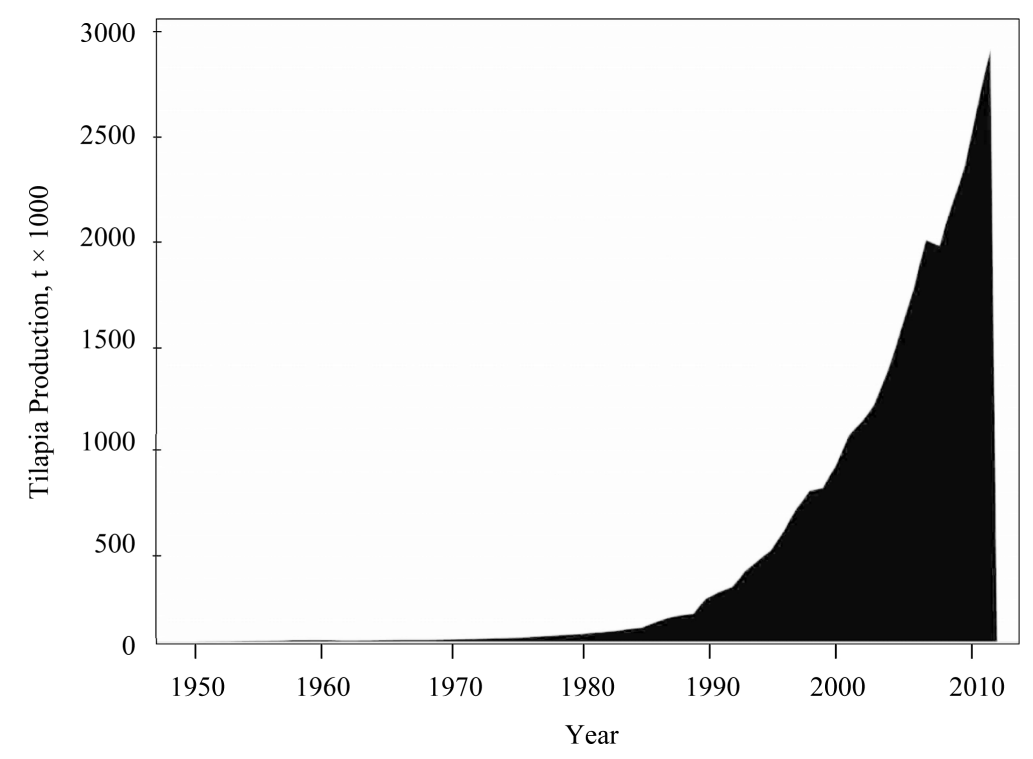

Figure 2. Annual worldwide tilapia aquaculture production, in metric tons $\times$ 1000, compiled with data from FishStat (FAO Fisheries and Aquaculture).

those produced 50 years ago [27]. A shortened production cycle yields vastly more meat than more time-consuming earlier operations; as summarized by Wideman and coworkers [28], "If humans grew at a similar rate, a $3 \mathrm{~kg}(6.6 \mathrm{lb})$ newborn baby would weigh $300 \mathrm{~kg}(660 \mathrm{lb})$ after 2 mo”.

Comparable efforts are underway to improve strains of the Nile tilapia for efficient mass production purposes. Among strains subjected to sustained programs of selective breeding, the Genetically Improved Farmed Tilapia, or GIFT tilapia [29] is among the best-publicized and most successful subjects. Breeding programs were initiated in the 1970's and have been continued by the Philippines Department of Fisheries, the WorldFish Center in Malaysia, then the International Center for Living Aquatic Resources Management (ICLARM), Central Luzon State University in the Philippines, the University of the Philippines Marine Science Institute, the Bureau of Fisheries and Aquatic Resources (BFAR) in the Philippines, and the Institute of Aquaculture Research (AKVAFORK) in Norway. Collectively, these efforts have produced pedigreed strains of tilapia that consistently display sharply improved growth and feed utilization rates on farms. Published data on the extent of improved growth rates and feed conversion ratios vary, but production costs for farmers using GIFT strain tilapia have reportedly been reduced by more than 30\% [30] [31]. Most Nile tilapia grown commercially in the Philippines are either GIFT tilapia, or genetically related strains [32]. Stocks of GIFT strain tilapia have been distributed to at least eleven tilapia-producing countries [33]. Growth of GIFT tilapia responds well to pond enrichment with organic manures in semi-intensive culture [34].

\section{Tilapia Culture Methods and Feeding Strategies}

Because of their robustness and versatility, tilapia are produced in culture systems ranging from do-it-yourself backyard tanks to commercial-scale intensive food production operations that target export markets. Marketingrelated image problems are less of an issue for local consumption in developing countries, many of which rely heavily on tilapia farming to meet their urgent demands for protein. Expanded tilapia culture in the Philippines has generated fish mainly for local markets, and per capita tilapia consumption has grown to about 3 times per week there [32]. The establishment of tilapia culture has been less straightforward in Bangladesh, where demand for tilapia has exceeded supplies as suitable culture technology and infrastructure are becoming established [32] [35].

Feeding costs are among the largest expenses in tilapia farming [36]. The amount and cost of food required for growout is dependent on choices of culture methods, feeding strategy, and stocking intensity [37], but expenses for feeds have been estimated to account for more than $70 \%$ of variable farming costs in the Philippines [32]. Alternatives for feeding tilapia include pelleted diets based on wheat, soybean oil meal, poultry and meat 
by-product meals, and fishmeal, diets based on pond plankton, and combinations of pellets and plankton. Fishmeal and fish oil, never very concentrated in tilapia diets, are still problematic in terms of cost and sustainability, so reliance on them should be minimized [24]. Traditional Asian tilapia culture has used farm products and by products as fertilizers on integrated terrestrial/aquatic farms to promote primary production in ponds. The integration of livestock production with aquaculture provides an efficient means of utilizing nutrients in farm manures for the production of other consumable products [38] [39]. The same approach to nutrient cycling is at the core of western organic farming methods. Nutrients derived from manure stimulate the production of phytoplankton and zooplankton in culture ponds, both of which tilapia readily consume. This is most readily applicable on small- and medium-scale integrated farms. Variation in the nutritional content of manures [40] and the fact that bacterial decomposition of animal manures may take weeks or months [41], make manure applications challenging on a mass scale. The total nitrogen and phosphorus content of swine manure each can vary by more than an order of magnitude, depending on the age of the animals, their feeds, temperature, moisture content, and other factors [40]. For this reason, routine chemical assessment of manure nutrient content is recommended, although chemical analyses are impractical in some parts of the world. Tilapia farming on a large scale generally does not rely on manure to stimulate aquatic plankton production; the variables discussed above are often eliminated by the use of formulated pelleted feeds and/or inorganic fertilizers of known composition.

Phytoplankton communities in culture ponds produce ample amounts of long-chain omega-3 fatty acids [42]. These compounds are either consumed directly when fish eat microalgae, or they are passed through the food chain by way of zooplankton. Tilapia are opportunistic feeders that also ingest macrophytes, bacteria and zooplankton, and they have been described as filter feeders because they are capable of removing plankton as small as 5 microns in diameter from the water column and ingesting them [37]. Pond phytoplankton favorably influence the nutritional lipid content of the organisms that consume them, and it is possible that the management of phytoplankton could provide a means of producing specialized tilapia with enhanced fatty acid profiles [43].

There are advantages and disadvantages to organic pond fertilization, when compared with the use of either inorganic fertilizers or formulated pelleted feeds. Feeds containing either fishmeal or alternative protein sources promote relatively faster growth, but at increased costs and with some environmental impacts. Reducing the amount of pelleted feeds during commercial tilapia culture lowers production costs by encouraging foraging, with no apparent impairment of growth, uniformity, or survival; this practice also prevents uneaten pelleted feeds from contaminating pond water with nutrients [36]. The degree of enhancement of plankton and fish productivity induced by the addition of manure is more variable than it is with the use of more precisely defined sources of nutrients. The consumption of a mix of planktonic species enhanced by pond fertilization provides nutritional and other advantages over wheat- and soy-based diets, which can be deficient in omega- 3 fatty acids [42] [44]. Inorganic fertilizers are marketed with known concentrations of nitrogen and phosphorus, eliminating the need for their measurement as in manures, but both organic and inorganic approaches promote plankton productivity. Inorganic fertilizers stimulate the propagation of phytoplankton, whereas organic fertilizers invigorate a more diverse community, including bacteria and heterotrophic zooplankton [45]. Modern terrestrial farming of field crops is reliant on inorganic fertilizers, but cost and availability can be problematic in the developing world. For centuries, pig and poultry manures have been used as fertilizers to promote plankton communities in ponds used for fish cultivation in China [46].

Traditional uses of fertilizers in ponds have been adapted recently to closed culture systems, resulting in the "green water method" [47]. This low-cost method is effective in the intensive aquaculture of larval and juvenile organisms because it provides abundant nutrients in a chemically stable environment with a positive oxygen balance [47]. Green water environments also appear to favor stable microbial communities with relatively few pathogens. Some saline and brackish green water systems repress a particularly destructive clade of bacteria that includes Vibrio harveyi, which causes luminous vibriosis [48], and Vibrio parahemolyticus, thought to be responsible for Early Mortality Syndrome (EMS) in Penaeid shrimp farming [49]. Brackish green water from Oreochromis urolepis hornorum (formerly known as Tilapia hornorum) culture ponds antagonizes Vibrio harveyi sufficiently to prevent luminous vibriosis in Penaeus monodon culture [50].

The use of pig manure as a source of nutrients for fish production makes good economic and ecological sense. Some integrated systems also promote the growth of aquatic plants with organic fertilizers, which are then used to feed the growing pigs [51]. Increases in pig production in China are attributed not only to their value for meat production but because pigs are viewed in China as a "costless fertilizer factory moving on hooves" [51]. Manures are not as nutrient-rich as inorganic fertilizers, but they efficiently promote robust algae blooms [52]. The 
nutritional value of pig manures to phytoplankton is variable; they contain not only the primary nutrients nitrogen, phosphorus and potash, but also supplies of secondary nutrients required by plants [40] and missing from many inorganic fertilizers. A balance of light supplemental feeding coupled with moderate to substantial manure application does not necessarily support the fastest growth, but is often identified as the most cost-effective feeding strategy [41] [53] [54].

Tilapia directly consume some manure, so pond fertilization with manure is frequently misinterpreted as the use of feces as food. Those arguments are often made in un-reviewed media (e.g. published online) with sensational titles and negative messages [55]. Many readers are unfamiliar with millennia of history of the use of farm manures as fertilizer, and have referred dismissively to the promotion of pond productivity with manure as feeding with sewage or "poop" [55]. The direct nutritional value of manure consumed by tilapia is minuscule in comparison with the nutrition acquired by grazing on algae and zooplankton; fish in integrated aquaculture and livestock/pig farms derive a secondary benefit from the consumption of undigested feeds present in pig manure [56]. Manures are essential to organic vegetable farming, but the possible presence of pathogens has led to firm but non-binding guidelines about the use of untreated manures [57]. Opinions are strong about the balance of beneficial and hazardous qualities in manures. United States Food and Drug Administration (FDA) guidelines for organic food production recommend that manures be treated to reduce the likelihood of transmission of pathogens through crops, and that the time between fertilization with manure and harvest should be extended [57], although compliance with these recommendations is voluntary. "We think of [manure] as the best thing in the world”, says organic farmer Jim Crawford, "and they [regulators] think of it as toxic and nasty and disgusting" [58].

Concentrated or large-scale applications of manure have negative consequences on water quality, reducing the intensity of tilapia cultures that can be supported [47], in part because of oxygen depletion [59]. Optimal applications of manure for aquaculture pond fertilization are light and frequent [41]. In the early 1980s, the optimum manure loading in tropical tilapia ponds receiving untreated piggery wastes was investigated by Hopkins and co-workers at the Freshwater Aquaculture Center in the Philippines [38]. They concluded that the highest net yields of fish were obtained with stocking densities of 60 pigs per 20,000 fish. Abruptly and excessively increasing nutrient availability promotes heavy phytoplankton blooms that can impair light penetration, resulting in threatening cycles of hypoxia. For these and other reasons, heavy manure applications are avoided in successful aquaculture.

Web-based news about tilapia in the US has been subject to exaggeration, and this un-reviewed medium can propagate inflammatory stories and misinformation. Online articles warning of Chinese tilapia raised "on diets of manure" have been accompanied by an illustration of silver carp, Hypophthalmichthys molitrix, incorrectly identified as "white tilapia" [60]. US Food and Drug Administration spokespeople deny in this report that fish are farmed on a diet of feces, but that article has been shared as an alert to consumers, embellished with obscene language and multiple exclamation points, and re-posted with the same mislabeled carp photograph [60]. Attempts to contact the publishers and the holder of the copyright on the misidentified carp photograph to alert them to this mistake have been unanswered, but the original article has been removed. A more reasoned view is presented in the primary scientific literature.

United Nations reports conclude that consumer attitudes about the safety and quality of aquaculture products can be affected by the perception of hazards that may be disproportionate to any real health or environmental risks [61]. A recent example is the claim that the consumption of tilapia is more dangerous to the health of the consumer than eating bacon [62], with little apparent regard for the hazards of ingesting saturated fats [63] accompanied by large quantities of sodium [64], and in contrast with the consistently favorable recommendations for tilapia consumption by the FDA, Seafood Watch, and other organizations (discussed below).

\section{Best Management Practices and Aquaculture Farm Certification}

Ranking seafoods by various health and safety standards and by indices of the sustainability of production strategies is a growing trend in consumerism in the US and in Europe. The proliferation of "Best Management Practices" or BMP guidelines, production industry standards, certification programs, seafood ranking and advisory guides, and codes of conduct has continued as the aquaculture industry strives for sustainability [24]. A growing market for certified aquaculture products is becoming established in North America and Europe, in recognition of the need for seafoods to be managed carefully and sustainably. Less than $5 \%$ of global aquaculture is cur- 
rently formally certified, in part because certification is a complex and expensive process that favors large, corporate producers in the developed world [65].

Current perceptions of tilapia in the USA are subject to raging debates-farmed tilapia are rated by various consumer advocates from "best choice" to "do not eat". Seafood Watch [66] bases highly favorable ratings on tilapia product quality and sustainability, noting the ecological advantages of fish farming that does not depend on increasingly scarce and expensive dietary fishmeal. Analyses of the environmental impacts of tilapia culture by Seafood Watch place it among highly-ranked seafood selections, and tilapia farmed in China have been upgraded from "Avoid" to "A Good Alternative" rating [66]. That favorable rating is anything but unanimous, though, and tilapia farming remains the subject of rumors and controversy [55]. Online reporting [67] includes a quote that fish "are fed raw sewage daily" by foreign workers who ship it to you to "...poison your friends and family". Tilapia have been berated for real and perceived flaws in nutritional content, as vectors for disease, and especially in reaction to their consumption of manures and other detritus. As observed by Picchetti [55], consumers unfamiliar with the dynamics of food webs find "...for some reason, using cow manure in the vegetable garden is normal and acceptable, while adding it into the water for fish is not”.

Most reviewers credit tilapia as having an agreeable taste, but they can acquire off flavors if cultured under unfavorable conditions. A recurring theme in critiques of tilapia is their moderately low content of long-chain omega-3 fatty acids, although the abundance of these compounds is determined by diet and can be improved. Greenpeace advocates tilapia because of their herbivory and fast growth, and laud the Nile tilapia as a potentially sustainable aquaculture species [68], but this organization also expresses serious concerns about their invasiveness as an escaped or introduced, non-endemic species [69]. Endorsement by Greenpeace of organic aquaculture [70] does not specifically mention or advocate the use of manures, focusing instead on the elimination of antibiotic and hormone use and the prohibition of genetic engineering. Organic aquaculture standards for the European Union (E.U.) [71] impose limitations on the use of fishmeal-based diets for tilapia production in ponds, instead favoring the use of natural and organic foods. These regulations specify that some production systems may require organic fertilization, but do not define a standard for the use of manures to enhance primary production in culture ponds. European organic aquaculture serves a tiny niche market and consumers may be unaware that the exclusion of formulated feeds and synthetic fertilizers in those regulations can be interpreted as an implicit endorsement of manures as a nutrient source [72], as in classic terrestrial organic farming. The U.K.based Soil Association has published organic aquaculture standards based on the E.U. regulations; these recognize the use of manure as a foundation of organic farming, and as an acceptable aquaculture practice [73]. Standards for organic aquaculture have not yet been established in the U.S.A. The National Organic Standards Board task force proposed standards for organic aquaculture in the United States intended to limit reliance on fishmeal and other externally-sourced materials, but without addressing the use of organic and inorganic fertilizers [74]. Discussion of the principles and practices under consideration for such standards include mention of tilapia "produced in accordance with the tenants of organic agriculture..." [75].

The use of sex reversal hormones for production of all male tilapia (which grow faster and reduce the opportunity for feral populations to develop from escapees) has also been mired in controversy. Formal aquaculture standards and certification guidelines generally prohibit the use of hormones in aquaculture, although the Global Aquaculture Alliance Best Aquaculture Practices certification makes an exception for the use of androgens for sex reversal in tilapia fry [76]. Still, direct applications of methyltestosterone in hatcheries for sex-reversal of food fish are unpopular with the organic community. However, use of estrogens to produce genetic males but phenotypic females, which are then used to produce YY males, who in turn are used to produce all male progeny to be reared as food fish seems to be acceptable. As the hormone treated fish are grandparents of the food fish, there is no chance of exogenous hormone residues in the fish to be consumed. A second system of hybrid crosses with two closely related species of tilapia also provides a highly skewed sex ratio, but requires careful pedigree monitoring and marking of virtually indistinguishable parents.

The identification of best management or optimal farming practices for tilapia has been slow to emerge. Widespread cultivation of closely related species in this family of fishes throughout tropical, subtropical, and even temperate regions demonstrates their versatility, and no one farming method or diet can be singled out as ideal, or so superior as to be recommended to the exclusion of alternatives. Omnivory and adaptability to varying degrees of culture intensiveness make tilapia poor candidates for rigid or highly specific BMP guidelines in the interest of farm certification. The original practice of subsistence farming in ponds or tanks in poor countries 
has given rise to mass culture for US, European, and Japanese markets. The assimilation of wastes, the propensity for diversion of energy into reproduction at a young age, and the desire to culture male-only crops are common challenges to tilapia farmers, and have been discussed elsewhere [77]. The escape of propagated specimens is also a pressing problem, since tilapia are notoriously invasive. Tilapias were widely introduced for weed [78] and insect [79] control in the 1960s and 70s, but such introductions have been difficult or impossible to contain and tilapia are now mentioned among the most invasive of fishes [80], especially in degraded ecosystems.

The use of manures in tilapia farming remains controversial and is often not addressed directly in BMPs or certification standards. Agreement is strong among various published standards for tilapia culture that antibiotics and hormone use should be avoided, and genetic engineering is often prohibited, but opinions are divided, contradictory, or unspoken about the use of manures. One study commissioned by the World Wildlife Fund [77] recommended that "certification probably should strictly forbid the use of animal or human wastes as fertilizers". The subsequent World Wildlife Fund (WWF) "Better Management Practices" analysis [81] did not go so far as that recommendation, concluding only that feeds and fertilizers should be applied sparingly. The WWF recommendations [81] were comparable to those found in Aquaculture Stewardship Council certification guidelines [82], which do not mention manure specifically. Diana [41] argued that "using animal manures for tilapia production... is actually much more productive and has no negative effects on water or fish quality.... certification standards not allowing animal manures should be reconsidered”. Global Aquaculture Alliance (GAA) Best Aquaculture Practices farming standards state that certified farms shall not use untreated manures [74]. Acceptable treatments for manures are not specified in the GAA standards; these may or may not include composting or aging, drying, fermentation, or other relatively low-cost means of deactivating microbes, but the stated concern is the spread of pathogens. Diana's analysis [41] led to the conclusion that manures stimulate production more effectively than inorganic fertilizers do, and that the careful use of manures for integrated aquaculture as practiced for centuries in Asia is highly efficient, posing little or no threat to human health.

The integration of terrestrial animal farming with tilapia culture is a common practice in many third world countries, particularly among farmers conducting semi-intensive tilapia culture. Animal houses are often situated on the pond dikes or over the pond water to facilitate the use of animal wastes to fertilize the pond. In a survey conducted by the Asian Development Bank (ADB) in the Philippines, the majority of tilapia farmers reported that they regularly use fertilizers in their culture ponds [32]. About $22 \%$ of tilapia farmers used organic fertilizers (mainly chicken manure) and a very small minority ( 2\%) did not use fertilizers at all, believing that their pond soil was fertile enough, or suspecting that fertilization could generate off-flavors in harvested fish [32].

In much of Asia, the small integrated family farm is being replaced with larger properties controlled by government agencies, cooperatives, or investors. In many cases these farms are switching to formulated feeds for ease of use, adherence to "western" inspired BMPs, due to farm specialization, or some combination of these. In addition, the feed companies also provide technical support for the farm to encourage farming success, greater profit and future increased sales of feed. However, there is still a strong recognition of the benefits of "green water" culture of juvenile tilapia in fertilized ponds. This serves to reduce overall costs and provide high health fish for final grow out on formulated feed diets.

There are also large numbers of multi-hectare polyculture fish farms in Asia that rear various mixes of carps, tilapias, pacu, Pangasius spp. and freshwater prawns. These farms operate with a mix of animal manures and formulated fish feeds. Placing a piggery, poultry house or duck/goose enclosure above a corner of the pond is still a common practice that reduces production costs, increases primary productivity and yields more edible protein per square meter. Until Western farmers develop farming technology that provides as much safe high quality food in the same space with fewer environmental impacts, web based complaints about the use of manures in aquaculture should be taken with healthy skepticism.

\section{Acknowledgements}

The authors thank Dr. Michael Rubino for his support of this and other aquaculture research activities within NOAA. The support and encouragement of the US Agency for International Development AquaFish Innovation Laband Director Hillary Egna are also deeply appreciated. We are also grateful for the help of Mr. EddieBoy Jimenez of the Freshwater Aquaculture Center at the Central Luzon State University in the Philippines. 


\section{References}

[1] UNDESA (United Nations, Department of Economic and Social Affairs, Population Division) (2013) World Population Prospects: The 2012 Revision, Highlights and Advance Tables. United Nations, New York.

[2] FAO (United Nations Food and Agriculture Organization) (2012) The State of World Fisheries and Aquaculture. 2012 FAO Fisheries Department, Food and Agriculture Organization of the United Nations, Rome.

[3] FDA (US Food and Drug Administration) (2014) Fish: What Pregnant Women and Parents Should Know US Food and Drug Administration, FDA and EPA Issue Draft Updated Advice for Fish Consumption. http://www.fda.gov/food/foodborneillnesscontaminants/metals/ucm393070.htm

[4] Larsen, J. and Roney, J.M. (2013) Farmed Fish Production Overtakes Beef. http://www.earth-policy.org/plan_b_updates/2013/update114

[5] Gormaz, J.G., Fry, J.P., Erazo, M., and Love, D.C. (2014) Public Health Perspectives on Aquaculture. Current Environmental Health Reports. http://link.springer.com/article/10.1007\%2Fs40572-014-0018-8\#page-1

[6] FAO (United Nations Food and Agriculture Organization) (2014) Conservation Agriculture. http://www.fao.org/ag/ca/

[7] Hobbs, P.R., Sayre, K. and Gupta, R. (2008) The Role of Conservation Agriculture in Sustainable Agriculture. Philoshophical Transactions of the Royal Society B: Biological Sciences, 363, 543-555.

http://dx.doi.org/10.1098/rstb.2007.2169

[8] Kirchmann, H., Thorvaldsson, G. (2000) Challenging Targets for Future Agriculture. European Journal of Agronomy, 12, 145-161. http://dx.doi.org/10.1016/S1161-0301(99)00053-2

[9] Flagg, T.A. and Mobrand, L.E. (2010) Conservation Aquaculture Approaches for Hatchery Reform. Bulletin of Fisheries Research Agency (Japan), 29, 85-91.

[10] Den Hartog L. (2004) Developments in Global Pig Production. Advances in Pork Production, 15, 17-24.

[11] Brown, L.R. (2006) Plan B 2.0: Rescuing a Planet under Stress and a Civilization in Trouble. W.W. Norton and Co., New York.

[12] Eshel, G., Shepon, A., Makov, T. and Milo, R. (2014) Land, Irrigation Water, Greenhouse Gas, and Reactive Nitrogen Burdens of Meat, Eggs, and Dairy Production in the United States. Proceedings of the National Academy of Sciences of the United States of America, 111, 11996-12001. http://dx.doi.org/10.1073/pnas.1402183111

[13] Krapac, I.G., Dey, W.S., Roy, W.R., Smyth, C.A., Storment, E., Sargent, S.L. and Steele, J.D. (2002) Impacts of Swine Manure Pits on Groundwater Quality. Environmental Pollution, 120, 475-492. http://dx.doi.org/10.1016/S0269-7491(02)00115-X

[14] Brown, S.B., Ikenberry, C.D., Soupir, M.L., Bisinger, J. and Russell, J.R. (2014) Predicting Time Cattle Spend in Streams to Quantify Direct Deposition of Manure for TMDL Development. Applied Engineering in Agriculture, 30, 187-195.

[15] FAO (United Nations Food and Agriculture Organization) (2006) Livestock’s Long Shadow—Environmental Issues and Options. http://www.fao.org/docrep/010/a0701e/a0701e00.HTM

[16] Gerber, P., Wassenaar, T., Rosales, M., Castel, V. and Steinfeld, H. (2007) Environmental Impacts of a Changing Livestock Production: Overview and Discussion for a Comparative Assessment with Other Food Production Sectors. In: Bartley, D.M., Brugère, C., Soto, D., Gerber, P. and Harvey, B., Eds., Comparative Assessment of the Environmental Costs of Aquaculture and Other Food Production Sectors: Methods for Meaningful Comparisons, FAO/WFT Expert Workshop, Vancouver, 24-28 April 2006, 37-54.

[17] Green, B.W. and Duke III, C.B. (2006) Pond Production. In: Lim, C.E. and Webster, C.D., Eds., Tilapia Biology, Culture, and Nutrition, Food Products Press, New York, 253-288.

[18] Boyd, C.E. (2006) Management of Bottom Soil Condition and Pond Water and Effluent Quality. In: Lim, C.E. and Webster, C.D., Eds., Tilapia Biology, Culture, and Nutrition, Food Products Press, New York, 449-467.

[19] Fitzsimmons, K. (2006) Prospect and Potential for Global Production. In: Lim, C.E. and Webster, C.D., Eds., Tilapia Biology, Culture, and Nutrition, Food Products Press, New York, 51-72.

[20] EPA (US Environmental Protection Agency) (2012) Ag-101. Poultry Production. http://www.epa.gov/oecaagct/ag101/printpoultry.html\#table

[21] Josupeit, H. (2005) World Market of Tilapia. GLOBEFISH Research Programme, Vol. 79, FAO, Rome.

[22] Josupeit, H. (2010) World Supply and Demand of Tilapia. FAO, Rome.

[23] Mader, S.S. (1996) Biology. 5th Edition, W. C. Brown, Dubuque.

[24] Waite, R., Beveridge, M., Brummett, R., Castine, S., Chaiyawannakarn, N., Kaushik, S., Mungkung, R., Nawapakpilai, 
S. and Phillips, M. (2014) Working Paper, Installment 5 of Creating a Sustainable Food Future. Improving Productivity and Environmental Performance of Aquaculture. World Resources Institute, Washington DC.

[25] Cressey, D. (2009) Aquaculture: Future Fish. Nature, 458, 398-400. http://dx.doi.org/10.1038/458398a

[26] Rosenthal, E. (2011) Another Side of Tilapia, The Perfect Factory Fish. The New York Times. http://www.nytimes.com/2011/05/02/science/earth/02tilapia.html?pagewanted=all\&_r=0

[27] Paxton, H. (2010) The Effects of Selective Breeding on the Architectural Properties of the Pelvic Limb in Broiler Chickens: A Comparative Study across Modern and Ancestral Populations. Journal of Anatomy, 217, 153-166.

[28] Wideman, R.F., Rhoads, D., Erf, G. and Anthony, N. (2013) Pulmonary Arterial Hypertension (Ascites Syndrome) in Broilers: A Review. Poultry Science, 92, 64-83. http://dx.doi.org/10.3382/ps.2012-02745

[29] Ponzoni, R.W., Nguyen, H.N. and Khaw, H.L. (2006) Importance and Implementation of Simple and Advanced Selective Breeding Programs for Aquaculture Species in Developing Countries. In: Proceedings of the 8th World Congress on Genetics Applied to Livestock Production, Belo Horizonte, 13-18 August 2006.

[30] Ridha, M.T. (2011) Evaluation of Monosex Culture of GIFT and Non-Improved Strains of Nile Tilapia Oreochromis niloticus in Recirculating Tanks. International Aquatic Research, 3, 189-195.

[31] Yosef, S. (2009) Farming the Aquatic Chicken: Improved Tilapia in the Philippines. In: Spielman, D.J. and Pandya-Lorch, R., Eds., Millions Fed: Proven Successes in Agricultural Development, International Food Policy Research Institute, Washington DC, Chapter 18.

[32] ADB (Asian Development Bank) (2005) An Evaluation of Small-Scale Freshwater Rural Aquaculture Development for Poverty Reduction. 164 p. http://www.adb.org/sites/default/files/pub/2005/Fresh-Water.pdf

[33] Gupta, M.V. and Acosta, B.O. (2004) From Drawing Board to Dining Table: The Success Story of the GIFT Project. Naga, Worldfish Center Quarterly, 27, 4-14.

[34] Ezeafurukwe, C.F., Osuagwu, L.E. and Ahaotu, E.O. (2013) Effect of Artificial Feed and Fertilization of Ponds on Growth and Body Composition of Genetically Improved Farmed Tilapia. International Journal of Agriculture and Bioscience, 2, 160-163.

[35] Ahmed, N., Young, J.A., Dey, M.M. and Muir, J.F. (2011) From Production to Consumption: A Case of Tilapia Marketing Systems in Bangladesh. Aquaculture International.

https://www.researchgate.net/publication/257519497 From production to consumption a case study of tilapia mar keting_systems_in_Bangladesh

[36] Bolivar, R.B., Jimenez, E.B.T. and Brown, C.L. (2006) Alternate-Day Feeding Strategy for Nile Tilapia Grow out in the Philippines: Marginal Cost-Revenue Analyses. North American Journal of Aquaculture, 68, 192-197. http://dx.doi.org/10.1577/A05-012.1

[37] Lim, C.E., Webster, C.D. and Li, M.H. (2006) Feeding Practices. In: Lim, C.E. and Webster, C.D., Eds., Tilapia Biology, Culture, and Nutrition, Food Products Press, New York, 547-559.

[38] Hopkins, K.D. and Cruz, E.M. (1982) The ICLARM-CLSU Integrated Animal-Fish Farming Project: Final Report. ICLARM Technical Reports 5, International Center for Living Aquatic Resources Management, Makati.

[39] Ogello, E.O., Mlingi, F.T. and Munguti, J.M. (2013) Can Integrated Livestock-fish Culture be a Solution to East Africa's Food Insecurity? A Review. African Journal of Food, Agriculture, Nutrition and Development, 13, 8058-8076.

[40] Chastain, J.P., Camberato, J.J., Albrecht, J.E. and Adams, J. (2003) Swine Manure Production and Nutrient Content. Chapter 3a. In: Confined Animal Manure Managers Certification Program Manual B Swine Version 3, Clemson University Cooperative Extension Service.

[41] Diana, J. (2012) Some Principles of Pond Fertilization for Nile Tilapia Using Organic and Inorganic Inputs. In: Mischke, C.C., Ed., Aquaculture Pond Fertilization: Impacts of Nutrient Input on Production, 1st Edition, John Wiley and Sons, Inc., Hoboken. http://dx.doi.org/10.1002/9781118329443.ch12

[42] Guedes, A.C. and Malcata, F.X. (2012) Nutritional Value and Uses of Microalgae in Aquaculture. In: Muchlisin, Z., Ed., Aquaculture, InTech.

http://www.intechopen.com/books/aquaculture/nutritional-value-and-uses-of-microalgae-in-aquaculture

[43] Brown, C.L., Vera Cruz, E.M., Bolivar, R.B. and Borski, R.J. (2012) Chapter 3. Production, Growth, and Insulin-Like Growth Factor-1 (IGF-I) Gene Expression as an Instantaneous Growth Indicator in Nile Tilapia Oreochromis niloticus (L.). In: Marco, S. and Liu, Z., Eds., Functional Genomics in Aquaculture, Wiley-Blackwell, Inc., Ames, 79-89.

[44] Brown, M.R., Jeffrey, S.W., Volkman, J.K. and Dunstan, G.A. (1997) Nutritional Properties of Microalgae for Mariculture. Aquaculture, 151, 315-331. http://dx.doi.org/10.1016/S0044-8486(96)01501-3

[45] Treece, G.D. (2000) Zooplankton Culture. In: Stickney, R.R., Ed., Encyclopedia of Aquaculture, John Wiley and Sons, New York, 1037-1044.

[46] Nash, C.E. (2011) The History of Aquaculture. Wiley Blackwell, Ames, Iowa. 
http://dx.doi.org/10.1002/9780470958971

[47] Neori, A. (2011) “Green Water” Microalgae: The Leading Sector in Aquaculture. Journal of Applied Phycology, 23, 143-149. http://dx.doi.org/10.1007/s10811-010-9531-9

[48] Tendencia, E.A. and dela Peña, M. (2003) Investigation of Some Components of the Greenwater System Which Makes It Effective in the Initial Control of Luminous Bacteria. Aquaculture, 218, 115-119. http://dx.doi.org/10.1016/S0044-8486(02)00524-0

[49] De Schryver, P., Defoirdt, T. and Sorgeloos, P. (2014) Early Mortality Syndrome Outbreaks: A Microbial Management Issue in Shrimp Farming? PLoS Pathogens, 10, e1003919. http://dx.doi.org/10.1371/journal.ppat.1003919

[50] io-Po, G.D., Leaño, E.M., Peñaranda, M.D., Villa-Franco, A.U., Sombito, C.D. and Guanzon Jr., N.G. (2005) Anti-Luminous Vibrio Factors Associated with the "Green Water" Grow-Out Culture of the Tiger Shrimp Penaeus monodon. Aquaculture, 250, 1-7. http://dx.doi.org/10.1016/j.aquaculture.2005.01.029

[51] FAO (United Nations Food and Agriculture Organization) (1977) China: Recycling or Organic Wastes in Agriculture. Report of the FAO Study Tour to the People’s Republic of China, 28 April-24 May 1977. FAO Soils Bulletin 40.

[52] Conte, F.S. (2000) Pond Fertilisation: Initiating an Algal Bloom. Western Regional Aquaculture Center, WRAC Publication No. 104 02-2000, Seattle.

[53] Ayaad, E.A. and Hassouna, M.E. (2003) Response of Nile Tilapia to Dietary Animal Protein Level and Poultry Manure Fertilizer Level in Earthern Ponds. Egyptian Journal of Aquatic Biology and Fisheries, 7, 213-227.

[54] Green, B.W. (1992) Substitution of Organic Manure for Pelleted Feed in Tilapia Production. Aquaculture, 101, 213222. http://dx.doi.org/10.1016/0044-8486(92)90025-G

[55] Picchietti, M. (2104) Be Careful What You Wish For. Aquaculture Magazine, 70-73.

[56] Edwards, P. (1985) Pigs over Fish-Ponds. Pig International, 15, 8-10.

[57] FDA (US Food and Drug Administration) (1998) Guidance for Industry: Guide to Minimize Microbial Food Safety Hazards for Fresh Fruits and Vegetables. http://www.fda.gov/food/guidanceregulation/guidancedocumentsregulatoryinformation/ucm064574.htm

[58] Charles, R. (2013) Organic Farmers Bash FDA Restrictions on Manure Use. NPR Morning Edition. http://www.npr.org/blogs/thesalt/2013/11/21/246386290/organic-farmers-bash-fda-restrictions-on-manure-use

[59] Changi, W.Y.B. and Ouyang, H. (1988) Dynamics of Dissolved Oxygen and Vertical Circulation in Fish Ponds. Aquaculture, 74, 263-276. http://dx.doi.org/10.1016/0044-8486(88)90370-5

[60] Netzfrauen (2014) Igitt—In Asienge züchtete Fische warden mittels Hühner-und Schweinekot aufgezogen. http://netzfrauen.org/2014/04/15/igitt-asien-gezuechtete-fische-werden-mittels-huehner-und-schweinekot-aufgezogen/

[61] FAO (United Nations Food and Agriculture Organization) (1997) Towards Safe and Effective Use of Chemicals in Coastal Aquaculture. Joint Group of Experts on the Scientific Aspects of Marine Environmental Protection, GESAMP Reports and Studies No. 65, FAO, Rome. http://www.jodc.go.jp/info/ioc doc/GESAMP/r65e.pdf

[62] Weaver, K., Ivester, P., Chilton, J., Wilson, M., Pandey, P. and Chilton, F. (2008) The Content of Favorable and Unfavorable Polyunsaturated Fatty Acids Found in Commonly Eaten Fish. Journal of the American Dietetic Association, 108, 1178-1185. http://dx.doi.org/10.1016/j.jada.2008.04.023

[63] Mozaffarian, D., Micha, R. and Wallace, S. (2010) Effects on Coronary Heart Disease of Increasing Polyunsaturated Fat in Place of Saturated Fat: A Systemic Review and Meta-Analysis of Randomized Control Trials. PLoS Medicine, 7, e1000252. http://dx.doi.org/10.1371/journal.pmed.1000252

[64] Cook, N.R., Cutler, J.A., Obarzanek, E., Buring, J.E., Rexrode, K.M., Kumanvika, S.K., Appel, L.J. and Whelton, P.K. (2007) Long Term Effects of Dietary Sodium Reduction on Cardiovascular Disease Outcomes: Observational Follow-up of the Trials of Hypertension Prevention (TOHP). British Medical Journal, 334, 885-888. http://dx.doi.org/10.1136/bmj.39147.604896.55

[65] Bush, S.R., Belton, B., Hall, D., Vandergeest, P., Murray, F.J., Ponte, S., Oosterveer, P., Islam, M.S., Mol, A.P.J., Hatanaka, M., Kruijssen, F., Ha, T.T.T., Little, D.C. and Kusumawati, R. (2013) Certify Sustainable Aquaculture? Science, 341, 1067-1068. http://dx.doi.org/10.1126/science.1237314

[66] Monterey Bay Aquarium (2014) West Coast Consumer Guide. Seafood Watch. http://www.seafoodwatch.org/cr/cr_seafoodwatch/download.aspx

[67] Snopes.com (2014) Do Not Eat Tilapia! http://www.snopes.com/food/warnings/tilapia.asp

[68] Greenpeace, U.K. (2012) What Fish Can I Eat? http://www.greenpeace.org.uk/oceans/what-you-can-do/better-buys-what-fish-can-I-eat

[69] Allsopp, M., Johnston, P. and Santillo, D. (2008) Challenging the Aquaculture Industry on Sustainability. http://www.greenpeace.org/international/en/publications/reports/challenging-the-aquaculture/ 
[70] Allsopp, M., Santillo, D. and Dorey, C. (2013) Sustainability in Aquaculture: Present Problems and Sustainable Solutions. In: Chircop, A., Coffen-Smout, S. and McConnell, A., Eds., Ocean Yearbook 27, Sponsored by the International Oceans Institute and the Marine Environmental Law Institute of Dalhousie University, Martinus Nijhoff Publishers, Leiden/Boston, 291-322.

[71] Szeremeta, A., Winkler, L., Blake, F. and Lembo, P., Eds. (2010) Organic Aquaculture-EU Regulations (EC) 834/2007, (EC) 889/2008, (EC) 710/2009—Background, Assessment, Interpretation. International Federation of Organic Agriculture Movements (IFOAM) EU Group, Brussels, CIHEAM/IAMB, Valenzno, Bari.

[72] Prein, M., Bergleiter, S., Ballauf, M., Brister, D., Halwart, M., Hongrat, K., Kahle, J., Lasner, T., Lem, A., Lev, O., Morrison, C., Shehadeh, Z., Stamer, A. and Wainberg, A.A. (2012) Organic Aquaculture: The Future of Expanding Niche Markets. In: Subasinghe, R.P., Arthur, J.R., Bartley, D.M., De Silva, S.S., Halwart, M., Hishamunda, N., Mohan, C.V. and Sorgeloos, P., Eds., Farming the Waters for People and Food. Proceedings of the Global Conference on Aquaculture 2010, Phuket, 22-25 September 2010, 549-567.

[73] Soil Association (2014) Organic Standards, Aquaculture Revision 17.2. http://www.soilassociation.org/LinkClick.aspx?fileticket=pM14JxQtcs4\%3D\&tabid=353

[74] NOSB (National Organic Standards Board) (2008) Final Recommendation Livestock Committee. Proposed Organic Aquaculture Standards: Fish Feed and Related Management Issues. http://www.ams.usda.gov/AMSv1.0/getfile?dDocName=STELPRDC5074508\&acct=nosb

[75] Burden, D. (2009) The Organic Aquaculture Quandary. Ag Marketing Resource Center/USDA. http://www.agmrc.org/commodities_products/aquaculture/the-organic-aquaculture-quandary

[76] Global Aquaculture Alliance (2014) Aquaculture Facility Certification Finfish and Crustacean Farms Best Aquaculture Practices Certification Standards, Guidelines. http://www.gaalliance.org/bap/standards.php

[77] Boyd, C.E. (2004) Farm-Level Issues in Aquaculture Certification: Tilapia. Report Commissioned by WWF. http://fisheries.tamu.edu/files/2013/09/Farm-Level-Issues-in-Aquaculture-Certification-Tilapia.pdf

[78] Courtenay Jr., W.R. and Robins, C.P. (1973) Exotic Aquatic Organisms in Florida with Emphasis on Fishes: A Review and Recommendations. Transactions of the American Fisheries Society, 102, 1-12. http://dx.doi.org/10.1577/1548-8659(1973)102<1:EAOIFW>2.0.CO;2

[79] Legner, E.F. and Medved, R.A. (1973) Influence of Tilapia mossambica (Peters), T. zillii (Gervais) (Cichlidae), Molliensia latipinna le Sueur (Poeciliidae) on Pond Populations of Mosquitoes and Chironomid Midges. Mosquito News, 33, 354-364.

[80] IUCN (International Union for Conservation of Nature) Species Survival Commission (2008) View 100 of the World's Worst Invasive Alien Species. Invasive Species Specialist Group. http://www.issg.org/worst100_species.html

[81] WWF (World Wildlife Fund) (2011) Better Management Practices for Tilapia Aquaculture: A Tool to Assist with Compliance to the International Standards for Responsible Tilapia Aquaculture. Version 1.0. http://www.asc-aqua.org/upload/ASC\%20Tilapia\%20Better\%20Management\%20Practices v1.0.pdf

[82] Aquaculture Stewardship Council (2012) ASC Tilapia Standard Version 1.0 Jan 2012. http://www.asc-aqua.org/upload/ASC\%20Tilapia\%20Standard_v1.0.pdf 
Scientific Research Publishing (SCIRP) is one of the largest Open Access journal publishers. It is currently publishing more than 200 open access, online, peer-reviewed journals covering a wide range of academic disciplines. SCIRP serves the worldwide academic communities and contributes to the progress and application of science with its publication.

Other selected journals from SCIRP are listed as below. Submit your manuscript to us via either submit@scirp.org or Online Submission Portal.
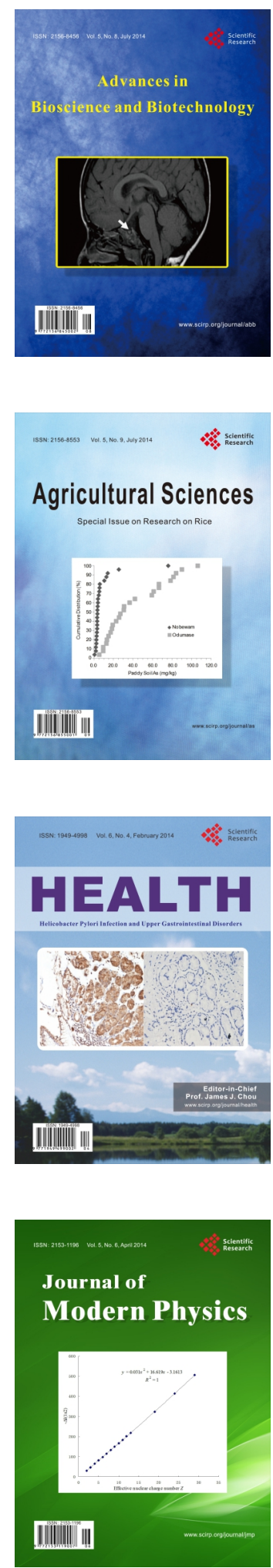
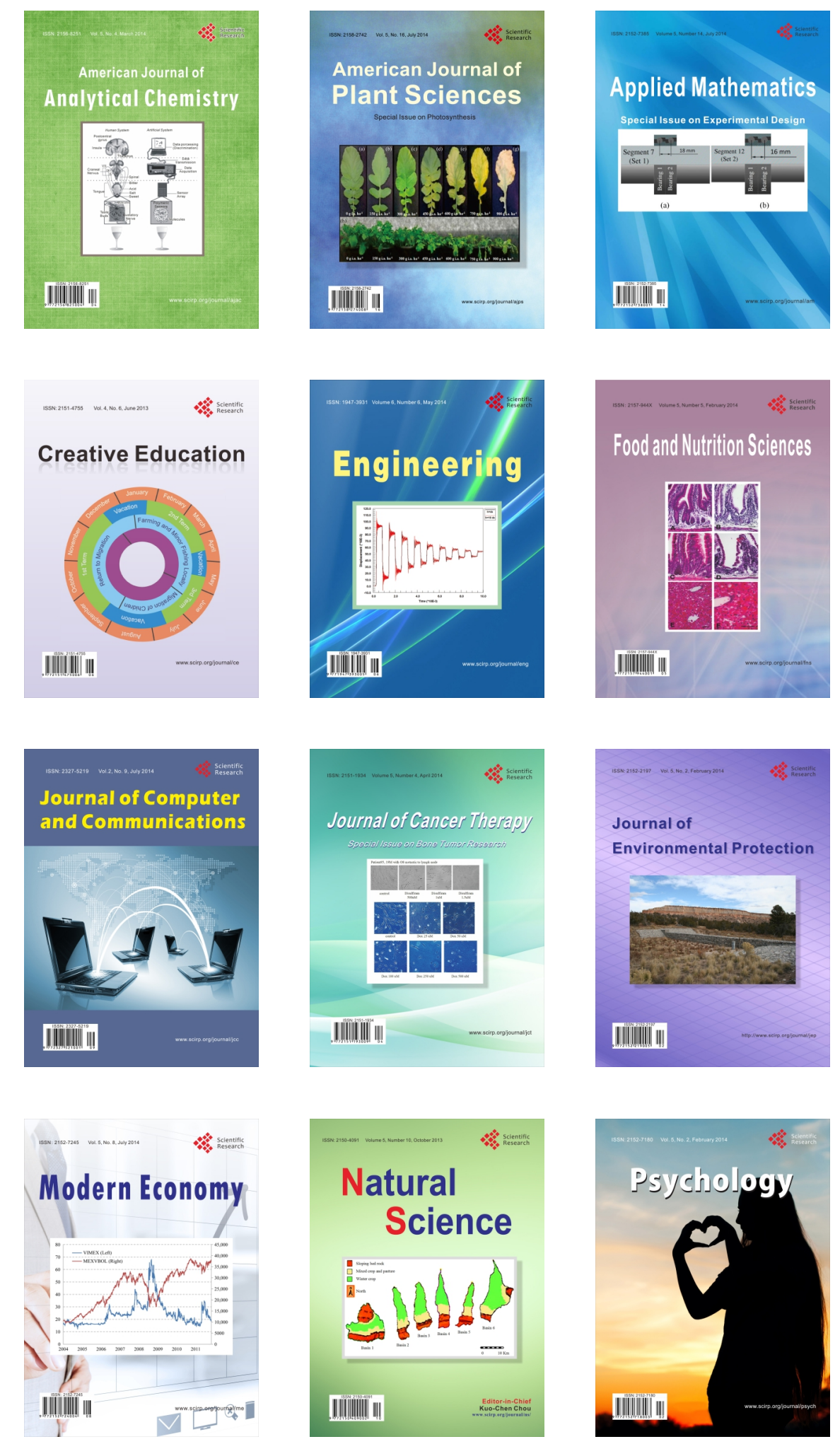